\title{
Reuna
}

\section{EVALUATION OF A SCALE ABOUT FEMALE PROPENSITY TO UNDERGO COSMETIC SURGERY}

\section{AVALIAÇÃO DE UMA ESCALA SOBRE PROPENSÃO FEMININA PARA CIRURGIA PLÁSTICA ESTÉTICA}

\author{
http://dx.doi.org/10.21714/2179-8834/2018v23n4p1-14
}

Cátia Fabíola Parreira de Avelar

Universidade Federal de Minas Gerais (UFMG), Brasil.

E-mail: catiaavelar@yahoo.com.br

\section{Ricardo Teixeira Veiga}

Universidade Federal de Minas Gerais (UFMG), Brasil.

E-mail: ricardo.necc@gmail.com

Submissão: 18 Abr. 2018 Publicação: 30 Mai. 2019. Sistema de avaliação: Double blind review. Centro Universitário UNA, Belo Horizonte - MG, Brasil. Editor geral: Prof. Dr. Gustavo Quiroga Souki

Este artigo encontra-se disponível nos seguintes endereços eletrônicos:

http://revistas.una.br/index.php/reuna/article/view/1024

http://dx.doi.org/10.21714/2179-8834/2018v23n4p1-14

\section{ABSTRACT}

This paper is about scale's development and evaluation, created to measure the women's propensity to undergo cosmetic surgery. A sample of 697 students from a large public Brazilian university to evaluate the scale was used. The propensity to undergo cosmetic surgery scale is proposed to measure someone's intention or desire to have cosmetic surgery. The scale has 6 items obtained from the translation of items available in the Marketing Scale's field. The sample was divided by 2 and exploratory and confirmatory factor analysis has been used to analyze data. The result shows that the scale is unidimensional, has validity and reliability $(\alpha=0.91)$. The scale can be used by scholars in future research and assist professionals and businesses related to the beauty industry in the segmentation of possible target audiences.

Keywords: Cosmetic surgery, Marketing Scales, Consumer behavior, Beauty, Gender 


\section{Resumo}

O presente trabalho consiste na construção e avaliação de uma escala para mensurar a propensão feminina para busca de cirurgia plástica com finalidade estética (CPE). Foi realizado um levantamento com 697 alunas de uma universidade federal brasileira para avaliação empírica do instrumento. $O$ construto foi conceituado como intenção ou desejo que uma pessoa tem em se submeter a um procedimento cirúrgico com finalidade estritamente estética e foi operacionalizado por meio de seis itens, elaborados a partir da tradução de escalas disponíveis na literatura internacional de Marketing. A amostra total foi divida aleatoriamente em duas subamostras para a análise dos dados empíricos, utilizando análises fatoriais exploratória e confirmatória. Os resultados demostram que a escala possui boas características psicométricas apresentando unidimensionalidade, validade e confiabilidade $(\alpha=0,91)$. A escala poderá ser utilizada em estudos futuros além de auxiliar na segmentação de possíveis públicos-alvo para profissionais e empresas relacionados com a indústria da beleza.

Palavras-chave: Gestão Estratégica, Análise Multivariada de Dados; Revisão Sistemática

\section{Introduction}

The number of plastic surgeries with aesthetics purpose (PSE's) has increased in several countries, including Brazil (DAVIS, 2002; DELINSKY, 2005; ELLIOT, 2009; HENDERSON KING; BROOKS, 2009; EDMONDS, 2007; MARKEY; MARKEY, 2009; MOWEN, LONGORIA; SALLEE, 2009; NASH, 2006; SHARMA, 2002; BRAZILIAN SOCIETY OF PLASTIC SURGERY [SBCP], 2016). For example, in 2016 almost 1.5 million surgeries with aesthetic purposes were carried out in Brazil (AMERICAN SOCIETY FOR AESTHETIC PLASTIC SUGERY [ASAPS], 2016), which represents an increase of $8 \%$ compared to the year 2015. It is worth noting that according to ASAPS (2016), Brazil is the second country in the world that performs PSE's (13.9 \% of surgeries performed by associated physicians), losing only to the United States (14.2\%), followed by Russia (5.6\%), Mexico (4.7\%) and India (4\%). Despite the increasing popularity of PSE's, social and psychological factors that influence attitudes about the theme were not fully explored (SHARP; TIGGEMANN; MATTISKE, 2014).

Aesthetic Plastic Surgery is defined as a type of surgical procedure used to reshape normal structures of the body, mainly to improve the appearance and selfesteem of the patient, different from reconstructive plastic surgery that seeks to repair abnormal structures of the body, with the aim of improving its function or provide (a) patient an appearance closer to normal, according to SBPC (2009).

There was an increase in the importance of beauty in recent decades, in which the body started to occupy a central role. According to Borelli and Casotti (2012), the valuation of youth and the pursuit of perfection index (characteristics of the cult of the body) led to a series of new consumption of goods and services related to search for the embellishment, such as exercises, specific treatments and plastic surgery, which grows and becomes every day more common, even in young women. In fact, the theme Beauty aroused interest in areas such as communication and psychology, 
including consumer behavior, in the last 50 years (STREHLAU; CLARO; NETO, 2015)

In the face of increased interest for services related to beauty, especially the PSE's and the academy interest for the theme, it sought to develop and evaluate a range of propensity to PSE, tested from a survey conducted with students from a Brazilian federal university, carried out in 2010. The research is part of a larger project, which investigated the relationship between personality and propensity to PSE. The scale can be used in studies about this behavior of consumption which includes in addition to the high cost, pain and risks to health. In addition, the scale could help in the search for possible segmentation of target publics for professionals and companies that want to offer such services, related services or services that offer body modifications without surgical intervention such as gyms, exercise programs and diets, personal trainers, among the various enterprises and professionals in the beauty industry.

The article is composed by this introduction followed by the theoretical framework that brings a brief exposition of some studies available in the literature about PSE's. The following chapter describes how the construct was operationalized and the assessments of validity and reliability. At the end of the article the limitations of the research are discussed, and new studies are suggested to the consolidation of the proposed scale.

\section{Theoretical background}

There is evidence of the practice of plastic surgery for centuries: in India, hundreds of years before Christ, there are records of attempts to reconstruct noses cut off as punishment for adultery. In the 16th century, techniques to alleviate facial scars, result of duels, were exploited in Italy (HAIKEN, 2000). Whereas in the 20th century, after the First World War, the surgeons realized that the techniques developed and improved in the reconstruction of faces of mutilated soldiers could be successfully applied to purely cosmetic purposes (EDMONDS, 2007), showing that PSE arises from advances in reconstructive plastic surgery (SHARMA, 2002). During the 20th century, technological innovations have continued, and the PSE scope has expanded to cover almost all parts of the body (CHATTERJEE, 2007).

Two streams of research were developed in the investigation of possible reasons and reasons for a person to undergo surgical modifications with aesthetic purposes: (1) anthropological and sociological studies that sought to understand how the structure of power in a society influences on culturally constructed meanings of human body and (2) studies in the area of psychology and marketing that address the issue of the motivations for the consumption of the procedure (PENTINA; TAYLOR VOELKER, 2009)

Studies in several areas indicate that women showed a greater propensity to cosmetic surgery than men (MOWEN; LONGORIA; SALLEE, 2009; SWAMI; CHAMORRO to PREMUZIC; BRIDGES et al., 2009; HENDERSON KING; BROOKS, 2009). Data from a survey conducted by ASAPS in 2016, show that women subjected themselves to $84.6 \%$ of all cosmetic surgeries performed by qualified professionals and associated with the institution. This fact can reflect the sociocultural pressure that women experience to fulfill idealized images of physical 
perfection, since women and girls are socialized to occupy themselves to enhance their physical appearance and are evaluated by others based on their attractiveness (HENDERSON KING; BROOKS, 2009). Edmonds (2002) suggests that the search for PSE's is associated with events in the life cycle of females and their consequences in appearance, such as puberty, pregnancy, breastfeeding and menopause.

Goldenberg (2005) proposes that there are three main reasons for making a PSE: mitigate the effects of aging, correct physical defects, sculpt a perfect body, being that in Brazil, the quest for a perfect body is the motivation that grows the most. Studies abroad, such as the Henderson-King and Brooks (2009) also proposed that people who seek and desire aesthetic plastic surgeries, indicate intrapersonal reasons (e.g., to alleviate dissatisfaction with the body or highlight the self-image) and social reasons (e.g., seem more attractive to someone or look younger for social reasons or business) Edmonds (2002) argues that the patients of PSE's are motivated by global human desire to adjust themselves in a social group.

As regards socio-cultural influences, materialism and the internalization of sociocultural messages emerged as significant predictors of acceptance and desire for plastic surgery, i.e., as more women have entered the social standards of attractiveness and more materialistic, they are, the more they will accept cosmetic surgery for psychological reasons (HENDERSON KING; BROOKS, 2009). DITMMAR (2008) shows in her studies that the internalization of standards of beauty is a moderating variable of the relationship between exposure to ultra-thin models and dissatisfaction with the body.

The influence of the media and communication vehicles of mass dissemination of behaviors and patterns of beauty must be considered in the investigation of the matter. In addition to technological and doctor progress, the nature of the quest for aesthetic plastic surgeries can be attributed to the existing social patterns of the "ideal" body disclosed by means of mass communication. Delinsky (2005) demonstrated that the probability of undergoing PSE in the future, was predicted by greater exposure to the media, which directly influences on people's knowledge and acceptance of the procedure. For Elliot (2009), the celebrity culture and consumerism are important factors for the understanding of the growth in the number of PSE's since that the emphasis given by the media in the bodies of celebrities and the culture of artificial beauty seems to inspire people to seek such a procedure. Sharp, Tiggemann and Mattisken (2014) showed that the effects of media exposure and the influence of peers on body dissatisfaction and attitude about searching for PSE 's were mediated by the degree of internalization of patterns of ideal beauty corroborating the results of work previously presented.

Studies in the area of Psychology and Marketing have addressed the issue of motivations for conducting PSE's. For example, Davis and Vernon (2002), Mowen, Longoria and Sallee, (2009), Soest et al. (2009) and Swami, Chamorro-Premuzic, Bridges et al. (2009) investigated the personality traits that predict the propensity to EPC's. Schouten (1991) investigated the reasons and the dynamics of self-concept, based on the behavior of symbolic consumption, in SEU ethnographic interviews suggesting facilitating factors in the choice of the procedure. Askegaard Gersten, and Langer (2002) emphasized the dominant role of the discrepancy between real selfconcept (the way a person really sees herself or himself) and ideal self-concept (the 
way a person would like to see) as a factor that motivates the body modifications by means of ECP's.

In Brazil, Strehlau, Claro and Neto (2015) found that there is no significant effect on the degree of feminine vanity on the implementation of EPC's and that the degree of esteem index has a negative impact on the propensity to EPC in women. Sante and Pasian (2011) investigated women requesting additional augmentation and/or liposuction (37) and women without looking for EPC (41) and the results suggested that there is greater dissatisfaction with one's own body appearance, high defensive attitude and greater emotional sensitivity in the group of women who wanted EPC's. Borelli and Casotti (2012) conducted in-depth interviews with 14 Brazilian women between 20 and 35 years, and the results showed that the decision to undergo an EPC seems to result from a combination of factors: A long period of deep dissatisfaction or discomfort with the body or with specific parts of the body; a period of specific stressful or difficult life; influence of someone who experienced a successful EPC; frustrated previous attempts to change the body.

\section{Development of the Scale}

The first step to operationalize a construct is the operational definition of the same, which provides information for the selection or planning of individual indicators. Constructs can be defined and operationalized in the same way as they were in previous studies, i.e., one can use constructs and identify scales that had good performance demonstrated in previous works (HAIR, BLACK, BABIN et al., 2010). Following this recommendation, a literature review was done about the theme. No scale of measurement for propensity to EPC's was adapted to the Brazilian context, but scales were found in international studies.

Mowen, Longoria and Sallee (2009) conducted a study with American women to test the propensity for EPC and tanning. In this study, the propensity to EPC was defined as intent or desire that a person has to undergo a surgical aesthetics procedure. This definition was used to operationalize the construct as well as its items, because it has proven to be one-dimensional and with good reliability $(\alpha>$ 0.83). In the same study, the authors showed that the scale of the propensity to EPC showed a correlation of $0.74(p<0.01)$ with the tendency of the person undergoing surgery in the future. This high correlation indicates predictive validity of the scale (Mowen, 2000). Due to the good performance of the scale, its items were considered.

Two items were added to the items chosen: "I would subject myself to the aesthetic plastic surgery, if it were free ' and "I would subject myself to the aesthetic plastic surgery, if I sure that the procedure is safe" because in a survey conducted in 2004 with women from 10 countries, Etcoff, Orbach, Scott and co-authors, found that $23 \%$ of women surveyed answered that they wanted to go through some EPC. Another question was added questioning about the desire to perform some EPC if it was sure that the procedure was safe and free and the number of women who wished to undertake a CPE has increased to $40 \%$. 
For adaptation of selected items, three bilingual individuals English / Portuguese were requested to translate the scales of English language to Portuguese. Checking the possible interpretations in translation versions were chosen that best indicated that the studied trait and that the interpretation would be clearer. The translation chosen was sent to an English teacher, with graduation in Languages, who made the reverse translation from Portuguese to English (back translation) with the aim of checking if the meaning of the sentence remained the same in both languages. After the process of translation and back-translation translated items presented in the form set out in TABLE 1.

\section{TABLE 1: Items of the scale propensity for Aesthetic Plastic Surgery}

\begin{tabular}{|c|c|c|}
\hline Coding & Original Item & Translated Item \\
\hline PropCPE1 & $\begin{array}{l}\text { I like the idea of having plastic surgery to } \\
\text { improve my appearance. }\end{array}$ & $\begin{array}{l}\text { Gosto da ideia de me submeter a cirurgia } \\
\text { plástica estética para melhorar minha } \\
\text { aparência. }\end{array}$ \\
\hline PropCPE2 & $\begin{array}{l}\text { I envision myself having plastic surgery to } \\
\text { make me look better. }\end{array}$ & $\begin{array}{l}\text { Eu me imagino fazendo cirurgia (s) plástica } \\
\text { (s) para ficar mais bonita. }\end{array}$ \\
\hline PropCPE3 & $\begin{array}{l}\text { If the opportunity arises, I would have } \\
\text { cosmetic surgery on my face. }\end{array}$ & $\begin{array}{l}\text { Se tivesse a oportunidade, faria cirurgia } \\
\text { plástica no meu rosto. }\end{array}$ \\
\hline PropCPE4 & $\begin{array}{l}\text { Overall, I believe that elective cosmetic } \\
\text { surgery can be a good thing. }\end{array}$ & $\begin{array}{l}\text { No geral, acredito que cirurgia plástica pode } \\
\text { ser algo bom. }\end{array}$ \\
\hline PropCPE5 & $\begin{array}{l}\text { Have you ever considered having any } \\
\text { type of cosmetic surgery performed on }\end{array}$ & $\begin{array}{l}\text { Eu me submeteria a cirurgia plástica } \\
\text { estética, se fosse de graça }\end{array}$ \\
\hline PropCPE6 & you if the procedures were safe and free & $\begin{array}{l}\text { Eu me submeteria a cirurgia plástica } \\
\text { estética, se tivesse a certeza que o } \\
\text { procedimento é seguro. }\end{array}$ \\
\hline
\end{tabular}

Source: Prepared by authors from Mowen et al. (2009) and Etcoff et al. (2004)

It is considered as real the validity once the instrument has been revised several times, even after the completion of pre-test, and its application did not generate negative feedback or results of respondents considered absurdities.

\section{Results}

Hair, Black, Babin et al. (2010) assert that when measures are developed for a study, some pre-test should be done, and this should use respondents similar to those of the population to be studied, with the aim of protecting regarding the adequacy of the test/scale. After the analysis of the pre-test the items that statistically do not present expected results (one-dimensionality, validity or reliability), require a refinement or elimination, to avoid problems when the final model is analyzed. In this study, we performed a pre-test with 57 questionnaires applied to students of the first period of an undergraduate course and students of the last period of post-graduate level degree lato sensu of a federal university, with the aim of assessing the adequacy of the scales used. The analysis of the data from the pre-test suggested that the scale has not presented problems of unidimensionality, validity or reliability and all its items were kept.

Analyzed the pre-test, the collection and analysis of data were begun. 697 questionnaires were collected in a convenience sample composed of undergraduate 
and graduate students of a federal university of a Brazilian capital. The sample was composed of $94.4 \%$ of students of undergraduate courses. More than half $(58.1 \%)$ of the students, were between 21 to 30 years; $31.6 \%$ were between 18 to 20 years; 50 students $(7.2 \%)$ were between 31 and 40 years; 14 students ( $2 \%$ of the sample) were 41 and 50 years and only 3 students $(0.4 \%)$ were above 51 years. GRAPH 1 shows the number of students classified by age range.

\section{GRAPH 1 - Number of students classified by age range.}

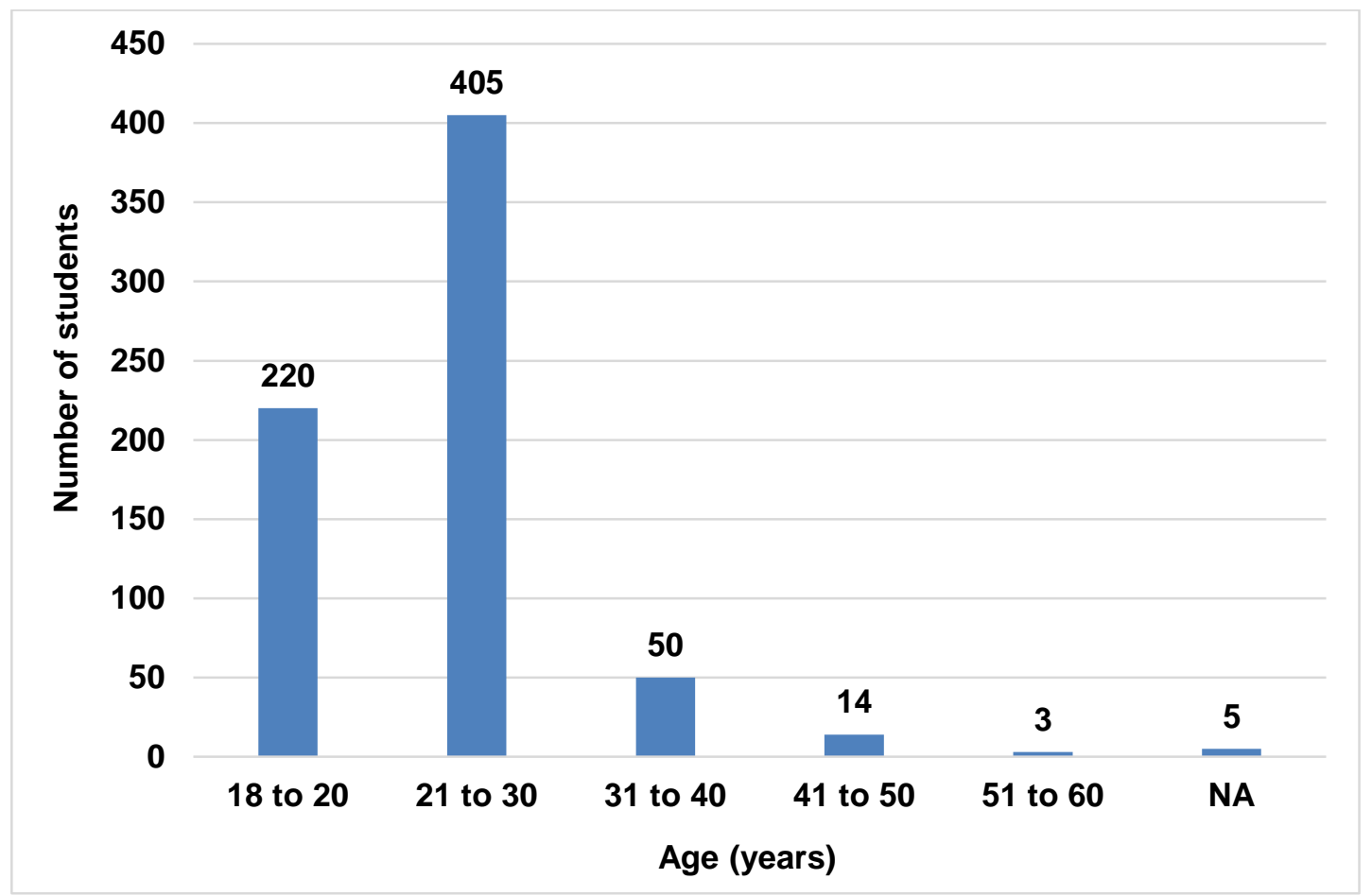

Source: Prepared by the authors

Most of the students in the sample (56.6\%) belonged to families earning up to 5 minimum wages per month and $16.9 \%$ of the students in the sample belonged to families who earned more than 12 minimum wages at the time. The majority of the students who responded to the survey were single ( $84.8 \%$ of the sample); $1.9 \%$ of the sample was separated or divorced and $9.9 \%$ were married or lived with a partner.

The examination of the data obtained was done with the aim of improving the estimates, the accuracy of the evaluation of the dimensionality of attributes and to ensure that the statistical assumptions inherent in the chosen technique for multivariate analysis of data have been met (as suggested by HAIR et al., 2005, page 47). The total number of lost data represented $1.02 \%$ of all collected data, i.e., of 3,642 units of information collected (697 cases X 6 variables), 37 were blank or invalid responses by double marking. The database showed 666 complete cases, which represents $96 \%$ of the number of students who participated in the data collection. Kline (2005, page 52), says that few lost data in a large sample, make the problem of lost data irrelevant. 
Despite the low number of lost data, an analysis was made as to its extent and its pattern of randomness. The tabulation of lost data by number of cases showed no pattern in the distribution of lost data. Such an absence of pattern suggests that the lost data are completely at random (MCAR). To confirm this hypothesis the data lost completely at random was performed using Little - MCAR test and the hypothesis that the data are missing completely at random (MCAR) was supported. It was opted to treat the lost data with the technique of replacing the average since the method is indicated when data has completely lost the chance, low levels of lost data and strong relationship among the variables (HAIR; BLACK; BABIN et al. 2010) as in this case.

In the stage of the research design and execution of empirical study to develop the scale, a sample of 697 valid questionnaires was randomly divided in two subsamples. In the first one (400 cases), exploratory factorial analysis (AFE) and analysis of internal consistency were performed The proportion of 66.67 points per variable is suitable for this type of analysis, because it exceeds the minimum requirement $10 \times 1$, appointed by the majority of authors (Hair et al., 2005, for example). In this step, AFE was used with the method of principal components, since the goal was to reduce data (Hair, Black, Babin et al., 2010) with Varimax rotation. To detect the number of factors, present the criterion of Kaiser was used (Eigenvalues $>1$ ). To evaluate the quality of the factor solution criteria suggested by Hair, Black, Babin et al. (2010) were used: total variance extracted from a factor of $\leq$ $60 \%$, Bartlett's Sphericity test, which presents statistical significance that the matrix has significant correlations with at least one of the variables (Sig. $<0.001$ ) and the Kaiser-Meyer-Olkin (KMO) adequacy test of the sample $>0.60$. The factor solution presented 1 factor with the following indexes: total variance extracted $=69 \%$; Sig. = 0.000 and $\mathrm{KMO}=0.90$, indicating that the solution found is adequate.

Proven the unidimensionality of the scale, it was continued with the reliability analysis. To estimate the internal consistency of the measures, it was calculated the Cronbach $\alpha$, whose values range from 0 to 1 , being the highest values indicating greater reliability among the indicators and the minimum acceptable value of 0.70 being possible to reach 0.60 in the case of exploratory research (HAIR; BLACK; BABIN et al., 2010). The $\alpha$ of the scale was 0.91 . The evaluation of the internal consistency of the scale indicates that this has good reliability. TABLE 1 presents a summary of the results obtained in the AFC.

Pasquali (2003) says that the construct validity is considered the most fundamental form of validity of psychological instruments today. Construct validity is the extent to which a set of measurable items reflects the theoretical latent construct that those items should be measured. Evidences of construct validity offer security that the measures of the items removed from the sample represent the true score that exists in the population. The construct validity is composed of four components, namely: (1) convergent validity (items indicators of a construct should converge or share a large proportion of variance in common with the factor), (2), discriminant validity (extension in which a construct is different from other constructs), (3) nomologic validity and (4) validity of expression or face validity (how the content of the items is consistent with the definition of the construct). 
Table 1 - Results of the Exploratory Factorial Analysis ( $\mathrm{N}=400)$

\begin{tabular}{lll}
\hline Criterion & Suggested values * & Values found \\
\hline Kaiser & Eigenvalues $>1$ & 1 \\
Total variance extracted from a factor & $\leq 60 \%$ & $69 \%$ \\
Bartlett's sphericity test & Sig. $<0.001$ & Sig $=0.000$ \\
Test Kaiser-Meyer-Olkin (KMO) & $>0.60$ & 0.90 \\
Cronbach's Alpha & 0.70 (acceptable) & 0.90 \\
\hline
\end{tabular}

Source: compiled by the authors from data of the research program worked in AMOS 7

Notes: * indices suggested by Hair, Black, Babin et al. (2010)

The confirmatory factor analysis (CFA) is a technique that allows to test how well the measured variables represent their constructs. FC was used to evaluate the relationships among the items (observable variables) and the construct propensity to EPC i.e., to assess the construct validity.

In the AFC the method of estimate of parameters by maximum likelihood (MV) was used, which is a method similar to that of ordinary least squares (GLS), but distinct (KLINE, 2005). The MV method was adopted due to being a robust method to violations of light and mild normalities, producing unbiased estimates of parameters (RIBEIRO; VEIGA, 2011).

It was built a model for measuring the program AMOS 7.0®, using all items of the scale and performed the analysis of the adjustment of the model of measurement with the reality represented by data from the subsample of the research, composed by 297 cases.

TABLE 2 presents the results of the AFC with values of the indices of general adjustment of the measurement model. According to indices suggested by Hair, Black, Babin et al. (2010 p. 645.646 and 686) the adjustment of the model is acceptable, since: (1) The p-value associated with the chi-square test of general model is insignificant as expected for a sample of over 250 respondents and a model with fewer than 12 items; (2) the value of the index of absolute fit (RMSEA) indicates a maladjustment because it was above the maximum point 0.07 ; (3) the value of incremental adjustment index $(\mathrm{CFI}=0.98)$ was very good because it was above the expected (0.97), but with the other indices suggesting model adequacy and (4) The chi-square test indicates an acceptable standard setting.

Table 2- Indices of quality of adjustment of the scale propensity for Aesthetic Plastic Surgery $(\mathrm{N}=297)$

\begin{tabular}{|c|c|c|}
\hline Adjustments Measurements & Measurement Model & $\begin{array}{l}\text { Indication of quality of the Adjustment } \\
\star\end{array}$ \\
\hline Chi-square test & 32.71 & Insignificant $\mathrm{p}$ value \\
\hline Degrees of Freedom & 9 & $\begin{array}{l}\text { Not applicable } \\
<2 \text { (very good); between } 2 \text { and } 5\end{array}$ \\
\hline Standard Chi-square & 3.63 & (acceptable) \\
\hline$p$-value & 0.000 & $>0.05$ \\
\hline $\mathrm{CFI}$ & 0.98 & $>0.95$ \\
\hline PNFI & 0.58 & The higher, the better \\
\hline RMSEA & 0.09 & $<0.07$ if $\mathrm{CFI} \leq 0.97$ \\
\hline
\end{tabular}

Source: compiled by the authors from data of the research program worked in AMOS 7 
Notes: * indices suggested by Hair, Black, Babin et al. (2010 pages 645,646 and 686) Considering the sample $>250$ respondents and model with lower than 12 observable variables; 2) estimate by MV method (Maximum Likelihood method); $\mathrm{CFI}=$ comparative fit index; PNFI = index of standard adjustment of parsimony; RMSEA = root mean square error of approximation

The indexes obtained are indicative of a good fit of the model to data from the subsample, because all the indicators presented have appropriate values, with the exception of RMSEA, which should be used in samples > 500 (HAIR, BLACK, BABIN et al., 2010). For this reason, the standard chi-square test is preferred and, in this case, had a value between 2 and 5, and, therefore, also in the recommended range.

After the model has been sustained, the convergent and discriminant validities of the measurement model were examined. There are a few ways to estimate the relative amount of convergent validity among the items of a test, namely: (1) factorial loadings, (2) extracted variance and (3) composite reliability.

In the case of convergent validity, (1) high loads on a factor indicate that the loads converge to some point in common. Hair, Black, Babin et al. (2010) suggest that all loads must be statistically significant and that the estimates of standardized loads should be $>0.5$ and preferably above 0.7 . (2) Average percentage of variance extracted (VE) in a set of items is also an indicator of convergence. VE is calculated as the total of all standardized loads of items of a squared construct (multiple squared correlations square) divided by the number of items (quadratic factorial load average). VE $\leq 0.5$ suggests appropriate convergence (HAIR; BLACK; BABIN et al., 2010). Another indicator of convergent validity suggested by the authors is the (3) composite reliability (also called construct reliability), which can be calculated by the following formula:

Conf. Comp. $=\frac{\left(\sum_{i=1}^{p} \lambda_{i}\right)^{2}}{\left(\sum_{i=1}^{p} \lambda_{i}\right)^{2}+\sum_{i}^{p} V(\delta)}$

Where:

$\lambda_{i}=$ carga padronizada para cada $i$-ésimo indicador

$V\left(\delta_{i}\right)=$ variância do termo erro para 0 i-ésimo indicador

$p=$ número de indicadores

In the calculation of the composite reliability, Hair et al. (1995, page 490) explain that the signal of negative charges should be disregarded upon totaling the standardized loads. In addition, they remember that $V(\delta)$ it is the error of measurement for each indicator, obtained as 1 -confiabilidade $=1-\lambda_{i}^{2}$. The authors suggest that reliability $\leq 0.70$ represents a good value and values between 0.6 and 0.7 may be acceptable, provided that other indicators of construct validity of a model are good.

The results show that all loads are significant, introducing the first criterion for convergent validity. The standardized loads were higher than 0.7 except the item PropCPE3; being: PropCPE1=0.88; PropCPE2 $=0.89$; $\quad$ PropCPE3 $=0.53$; PropCPE4=0.73; PropCPE5=0.81 and PropCPE6=0.80. The average variance 
extracted from the scale was adequate $(0.57)$ as well as the composite reliability (0.91). These values ensure the convergent validity of the construct. Figure 1 shows the standardized loads of multiple square correlations of the scale.

\section{FIGURE 2 Standardized loads of items in the scale of propensity to plastic surgery and their squared multiple correlations}

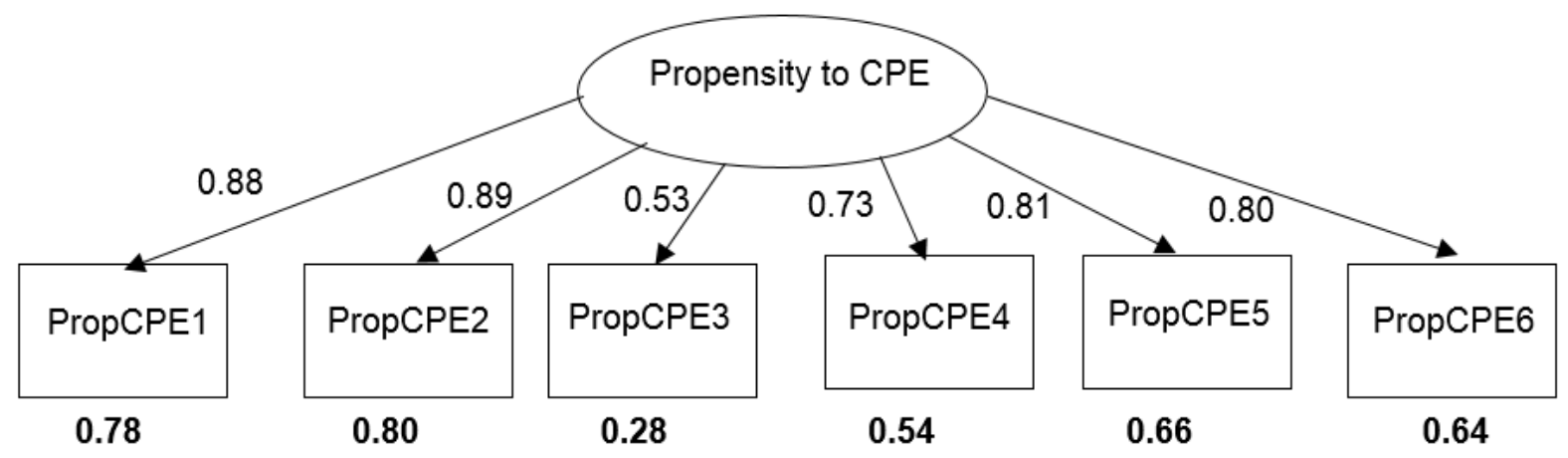

Notes: Source: Data analysis in AMOS 7.0 program

1) values in bold = standardized squared load or squared multiple regression;2) values near the arrows $=$ standardized load; 3 ) all loads are significant $(p<0.000)$

\section{Final considerations}

The study shows that the scale propensity for aesthetic plastic surgery is valid, although necessary improvements are necessary. From recommended procedures in specific literature on the development and evaluation of scales, results were obtained that show that the scale has good psychometric properties: it has dimensionality, validity and reliability.

However, the present study presents limitations: The use of a nonprobabilistic sample prevents the generalization of the data making necessary the achievement of future studies seeking more comprehensive and probability samples. Another limitation associated with the sample is related to the age of respondents since the young age of the sample (more than half are less than 30 years ) may have biased the data once that possibly a large part of the respondents has no strong effects caused by age or characteristics that lead to the desire for a surgical intervention. Another fact that may have influenced the responses is that a large part of the respondents does not have children at the time of data collection and Edmonds (2002) suggests that the search for EPC's is associated with events in the life cycle of females and their consequences in appearance, such as puberty, pregnancy, breastfeeding and menopause. These facts suggest the application of the study in women at a more advanced age and with children. Thus, the final reapplications of final scale in other samples are indicated, to ensure its reliability, validity and for possible generalizations of the submitted data. It is suggested, for example, besides the examples cited, apply the scale in people with different levels of income and schooling as well as in samples with people of the male sex. Another suggestion is the investigation of its predictive validity or criterion, applying it in a sample of people with plastic surgery already marked or which has already performed the procedure in the past assuming higher scores for persons who have RELNA, Belo Horizonte - MG, Brasil, v.23, n.4, p.I-14, Dut. - Dez. 2018 - ISSN 2179-8834 
performed this procedure or will be shortly. Finally, the item PropCPE 3 proved that has an acceptable $v$ but below the recommended (0.7), thus it is suggested the improvement of such an item because it relates to cosmetic surgery on the face.

The proposed scale enables the investigation of the search for a service that includes pain, risks and a significant financial investment could contribute to the discovery of the most effective means of influencing the behavior of consumption of this type of service, either encouraging the search for performing the procedure or demarketing campaigns in artificially stimulated demand. In addition, the instrument can be used to segment a consumer market, as the level of propensity to plastic surgery and the profile of consumers associated to this kind of consumption. We believe that another contribution of this study is to describe the process of creation and empirical evaluation of a scale translated to the Brazilian context. Such a procedure could help researchers who have as objective to use scales created and evaluated in other cultures in studies conducted in Brazil.

\section{References}

ASKEGAARD, Soren; GERSTEN, Martine Cardel; LANGER, Roy. The Body Consumed: Reflexivity and Cosmetic Surgery. Psychology \& Marketing, v.19, n.10, p. 793-812, out. 2002.

BORELLI, Fernanda; CASOTTI, Leticia. The before and after: a study of plastic surgery consumption with young women in Brazil. ACR North American Advances, 2012.

CHATTERJEE, Anjan. Cosmetic Neurology and cosmetic surgery: parallels, predictions and challenges. Cambridge quarterly of healthcare ethics, v.16, n. 2), p. 129-137, 2007.

DAVIS, Kathy. A dubious equity: men, women and cosmetic surgery. Body and Society, v.8, n. 1, p. 49-66, 2002.

DAVIS, Deborah; VERNON, Michael. Sculpting the body beautiful: attachment style, neuroticism and the use of cosmetic surgery. Sex Roles, v. 47, n.3-4, p. 129-138, ago. 2002.

DELINSKY, Sherrie Selwyn. Cosmetic surgery: a common and accepted form of self improvement? Journal of Applied Social Psychology, v. 35, n. 10, p. 2012-2028, 2005.

DITTMAR, Helga. Consumer culture, identity and well-being: The search for the "good life" and the "body perfect". New York: Psychology press, 2008.

EDMONDS, Alexander. No universo da beleza: notas de campo sobre cirurgia plástica no Rio de Janeiro. In: GOLDENBERG, Mirian. Nu \& Vestido: Dez antropólogos revelam a cultura do corpo carioca. Rio de Janeiro: Record, 2002. p. 189-261. 
EDMONDS, Alexander. The poor have the right to be beautiful: cosmetic surgery in neoliberal Brazil. Journal of the Royal Anthropological Institute, v.13, p. 363-38, 2007.

ELLIOT, Anthony. Drastic plastic and the global electronic economy. Society, v. 46, p. 357-362, 2009.

ETCOFF, Nancy; ORBACH, Susie; SCOTT, Jennifer; D'AGOSTINO, Heidi. "The real truth about beauty: a global report": Findings of the Global Study on Women, Beauty and Well-Being. White paper, 2004 . Disponível em www.therealbeatycampaign.com, acesso em 12 de maio de 2010.

GOLDENBERG, Mirian. Gênero e corpo na cultura brasileira. Psicologia Clínica, v. 17 , n.2, p. 65-80, 2005.

HAIKEN, Elizabeth. The making of the modern face: cosmetic surgery. Social Research, v. 67, n. 1, p. 81-97, jan./fev. 2000.

HAIR, Joseph et al. Análise Multivariada de Dados. 5. ed. Porto Alegre: Bookman, 2005.

HAIR, Joseph; BLACK, William; BABIN, Barry; ANDERSON, Rolph. Multivariate data analysis. $7^{\text {th }}$ Ed. New York: Pearson Prentice Hall, 2010.

HENDERSON-KING, Donna; BROOKS, Kelly. Materialism, sociocultural appearance messages, and paternal attitudes predict college women's attitudes about cosmetic surgery. Psychology of Women Quarterly, v. 33, p.133-142, 2009.

INTERNATIONAL SOCIETY OF AESTHETIC PLASTIC SURGERY. The international study on aesthetic/cosmetic procedures performed in 2016. Disponível em https://www.isaps.org/wpcontent/uploads/2017/10/GlobalStatistics2016-1.pdf . Acesso em : 1 mar. 2018.

KLINE, Roy. Principles and practice of structural equation modeling. 2nd ed. NewYork: The Guilford Press, 2005.

MARKEY, Charlotte; MARKEY, Patrick. (2009). Correlates of Young Women's Interest in Obtaining Cosmetic Surgery. Sex Roles, v. 61, p. 158-166, 2009.

MOWEN, John The 3M model of motivation and Personality: theory and empirical applications to consumer behavior. Boston: Kluer Academic Publishers, 2000.

MOWEN, John; LONGORIA, Adelina; SALLEE, Amy. Burning and Cutting: identifying the traits of individuals with an enduring propensity to tan and to undergo cosmetic surgery. Journal of Consumer Behavior, v. 8, p. 238-25, set./out. 2009.

$\mathrm{NASH}$, Karen. Men electing cosmetic procedures in growing numbers. Cosmetic Surgery Times, v.6, mai. 2006.

PASQUALI, Luiz. Psicometria: Teoria dos testes na Psicologia e na Educação. Petrópolis: Ed, Vozes, 2003. 
PENTINA, Iryna; TAYLOR, David; VOLKER, Troy. The roles of self-discrepancy and social support in young females' decisions to undergo cosmetic procedures. Journal of Consumer Behaviour, v.8, p. 149-165, jul./ago. 2009.

RIBEIRO, Juliane; VEIGA, Ricardo Teixeira. Proposição de uma escala de consumo sustentável. Revista de Administração, v. 46, n. 1, p. 45-60, 2011.

SANTE, Ana Beatriz; PASIAN, Sonia Regina. Imagem corporal e características de personalidade de mulheres solicitantes de cirurgia plástica estética. Psicologia: Reflexão e Crítica, v. 24, n. 3, p. 429-437, 2011.

SCHOUTEN, John. Selves in Transition: Symbolic Consumption in Personal Rites of Passage and Identity Reconstruction. Journal of Consumer Research, v. 17, p. 412-425, mar. 1991.

SHARMA, Vijay. (2002). Changing faces: patient information on cosmetic surgery Part 1. International Journal of Cosmetic Surgery and Aesthetic Dermatology, Bombai, v. 4, n. 4, p. 269-278, 2002.

SHARP, Gemma; TIGGEMANN, Marika; MATTISKE, Julie. The role of media and peer influences in Australian women's attitudes towards cosmetic surgery. Body Image, v. 11, n. 4, p. 482-487, 2014.

SOCIEDADE BRASILEIRA DE CIRURGIA PLÁSTICA. Cirurgia plástica no Brasil, 2009. Disponível em <http://www.cirurgiaplastica.org.br/publico/index.cfm>. Acesso em 10 fev. 2010.

SOCIEDADE BRASILEIRA DE CIRURGIA PLÁSTICA. Censo 2016 Situação da Cirurgia Plástica no Brasil; Análise Comparativa das Pesquisa 2014 e 2016. Disponível em <http://www2.cirurgiaplastica.org.br/wpcontent/uploads/2017/12/CENSO-2017.pdf>. Acesso em 23 mar. 2018.

SOEST, Tilmann von, et. al. Cosmetic surgery and the relationship between appearance, satisfaction and extraversion: testing a transactional model of personality. Journal of Research in Personality, v. 43, n.6, p. 1017-1025, 2009.

STREHLAU, Vivian Iara; CLARO, Danny Pimentel; NETO, Silvio Abrahão Laban. A vaidade impulsiona o consumo de cosméticos e de procedimentos estéticos cirúrgicos nas mulheres? Uma investigação exploratória. Revista de Administração, v. 50, n. 1, p. 73-88, 2015.

SWAMI, Viren; CHAMORRO-PREMUZIC, Tomas; BRIDGES, Stacy, FURNHAM, Adrian. Acceptance of cosmetic surgery: Personality and individual difference predictors. Body Image, v. 6, p. 7-13, 2009. 